\title{
SACRED SITES AND NOT-SO-DIRTY MONEY IN DAGHESTAN, NORTH CAUCASUS
}

Pilgrimages to the sacred sites in the North Caucasus have become very popular since the fall of the USSR. In some places the renovation of tombs of Sufi sheiks was financed and controlled by the state. Impressive buildings were erected, dirt roads were turned into asphalt roads. In other places, however, renovation, sometimes equally impressive, was sponsored by private benefactors. I argue that it is worthwhile taking a closer look at these sacred spaces through the lens of financial contributions. It may offer us an insight into the interplay of identities and social divisions and also inform us about the state's presence in a given setting.

In this paper I take as an example the shrine of sheikh Hasan, located in Daghestan in the mountainous village of Shiri where I conducted fieldwork between 2012 and 2017. I scrutinise the narratives and practices of local villagers and pilgrims from the lowlands who visit the site. I show how private financing of the shrine contributes to the preservation of ethnic and lineage identity as well as to the reproduction of social divisions.

The Republic of Daghestan is the most ethnically diverse and the most politically unstable region in the Russian Federation, where everyday life is permeated by state and anti-state violence. As a result, many Daghestanis move to different Russian cities, some turn to Sufi brotherhoods or Salafis, some join ISIS. The rest, perhaps the majority, stick to insular communities, relying on people they trust, people originating from their villages and tukhums, ${ }^{1}$ who live both inside and outside of Daghestan.

Shiri is a settlement in the Dakhadaevsky District known for its shrine of sheikh Hasan, an Arab missionary who was killed in nearby Kubachi at the beginning of the 14th century. The shrine consists of a tomb, a prayer house and a new mosque. In Shiri there are six households and around a dozen inhabitants. The nearest shop and polyclinic are in Kubachi located within a 40-minute drive on a dirt road that is usually accessible only by a four-wheel-drive and sometimes entirely inaccessible after heavy rainfall. Until 2016 the village was inhabited by Shiri and Tselibki people, who speak distinct Dargwa languages. They were assigned by Soviet linguists to the Dargi people, the second-biggest ethnic group in Daghestan, with a population of around $510,000 .^{2}$ The Shiris and Tselibkans enjoy similar material, but not social status. The latter are treated by Shiris as 'guests', who can be expelled at any time, which actually happened in 2016.

Looking at sacred places in the North Caucasus, I was interested in religious practices. However, when I started exploring the shrine, the dominant narratives were about benefactors: who paid for what, along with the price for every object. I learned that "we owe it all to our respectable Shiri people". Drawing on Keith Hart and Horacio Ortiz (2014) and their suggestion that money is integral to the hierarchies and networks of exchange through which it circulates, I see money from the

\footnotetext{
* The research was part of a project Documenting Dargi Languages in Daghestan: Shiri and Sanzhi, based at the University of Bamberg and financed by the Volkswagen Foundation. This paper is also a result of a research grant number 2015/19/D/HS3/02362 financed by Narodowe Centrum Nauki (National Science Centre).
} 
benefactors as working towards reproducing social divisions as well as strengthening identity. Below, I quote the edited excerpts from my field notes from 2012-2016. I show that the financing of the shrine's infrastructure works towards strengthening Shiri and lineage identity and the reproduction of traditional social divisions, deemed unimportant.

Driving to Shiri for the first time, in 2012, we stopped to see if the road was passable. "Look, they have built this big mosque recently. Well, they have always been welloff", Rasul pointed to an impressive building, visible from far away, quite big for an otherwise small village. Was it meant to inspire awe in neighbors? It certainly impressed Rasul. "How did they transport all the materials on such a road?"

It was only before the holiday of sheikh Hasan that the road has been renovated: thanks to the donations for the shrine, an excavator has been rented and villagers worked with shovels for over 12 hours trying to make the road passable. The electric poles needed to supply electricity for the shrine were also installed. A Shiri benefactor was praised for that. It turned out, however, that the head of the district administration also contributed. "He was angry when he learned that our co-villager gave more"- said Ibragim. "'Who is he? What does he do?' he inquired. I told him that he just trades tomatoes and cucumbers" - Ibragim did not want to disclose the profession of the benefactor in front of a civil servant he considered distrustful and corrupt. He was proud of not overtly praising the state official.

When the holiday in June 2013 was approaching, Patimat took me to the new mosque to do some cleaning. It has not been used for a year. She pointed at plastic windows, the mosaic floor and chandeliers. "It was our Shiri person, my nephew, who works at the border who paid for all." "He helped erect the place." [...] "He bought all the lamps. Each of the lamps cost 10,000 rubles." I ventured to ask if she knew where he had the money from. "You know, it's Daghestan" she just smiled. It was the tukhum Patimat belonged to that has excessively financed the shrine infrastructure, other tukhums, however, also contributed. Hadizhat, from a different tukhum, took me to the small prayer room and told me, as the first thing, that it was her cousin who renovated it so neatly. Different people took me to the shrine but it was only later that I realized that Tselibkans never visited the shrine on their own. For them it was a 'Shiri's shrine'. Tselibkans participated in prayers but did not contribute to the shrine's up-keeping.

The sheikh Hasan shrine was said to be the repository of baraka, divine grace and blessing. During the feast taking place between June 20 and 22 visitors brought offerings, money, sheep, and sweets. For the sake of their families or in gratitude, mavlids ${ }^{3}$ were being performed. They were led by men, with women following the men's prayer and the rhythmic La ilaha illa'llah. ${ }^{4}$ After each mavlid part of the donation was left to serve the community needs; the rest, along with products, was given away as sadaqa (voluntary charity) to all participants. When I asked Shiri people in the lowlands why they join the holiday, they pointed, first of all, to the 'getting together' aspect. Making connections, teaching their children about their roots and encouraging them to continue the tradition of within-tukhum marriages were also mentioned. Every time I asked about the holiday, the benefactors were praised.

Daghestani society generally respects those who make plenty of money or make a career; the respect is also shown to the families of such individuals. It is, however, important that the individuals help one's tukhum or the whole village. Their status emerges not from having money or spending money, but from investing it into the community. It is the community that transforms the benefactors' money into social status, which further spreads to the whole tukhum and the community. Donations reinforce ethnic and lineage identity in three ways: through praise narratives, by advancing the holiday status and 
through the awe the infrastructure inspires.

Praise narratives are spread not only among co-villagers but also among neighbours. Wealthy people who gained their money working in state positions (that is, in most cases, deriving income from kickbacks and bribes) are usually disregarded and seen as corrupt. If they, however, support the community, they can (re)establish their status. The head of administration tried to repair his reputation among Shiris with a donation, but failed: for his humble contribution he was more likely to be mocked than praised. The praise narratives serve, therefore not only as whitewashing of the (allegedly) dirty money and 'not always so impeccable' reputation of the benefactor, but also as a means through which respect for the benefactor is spread to those who praise him, and eventually to all Shiri people, seen by neighbours as one ethnolinguistic group. Being seen as respectable is closely connected to being seen as noble, which still holds strong symbolic capital, especially in regard to match-making. In the lowlands, when asked about their ethnic belonging, Shiri people were twice as likely to identify as Shiri, while Tselibnaks more often called themselves Dargi, downplaying the significance of ethnicity with Soviet-style equality narratives.

Infrastructure is the most visible object through which the transformation of the benefactor's money into social status in the community occurs. The visibility of the privately sponsored buildings, in particular the huge mosque, now well-lit and visible from a distance, helped Shiri people reproduce (among inhabitants of neighbouring villages) their

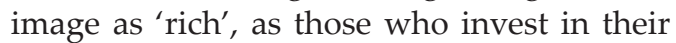
home village in times of increased mobility.

The benefactors' presence and donations advanced the status of the celebration. The feast connected the village to the broader world along the tukhum and ethnic ties, strengthening their identity and allowing them to 'keep the state at hand' and instead of relying on the state administration, count on influential benefactors. The fact that money for the infrastructure arrived usually as a pious donation for the shrine was also significant. In this way the material and moral order of the earthly community was extended into eternity.

I tried to demonstrate that it is worthwhile taking a closer look at the financing of shrine infrastructure as it offers us an insight into identities, social divisions and the relationship between the community and the state. Infrastructure along with the figures of benefactors helped to sustain the image of Shiri as noble and rich, distinct from other Dargi people and partly independent from the state administration.

\section{Iwona Kaliszewska \\ (University of Warsaw)}

\section{Notes}

1 Community of blood relatives (through the male line), formerly existing only within a territorial and political unit (dzhamaat).

2 Whether or not we see 'shiriness' as an ethnic or local identity is a political quesiton.

3 The recitations of specially written poems to commemorate the Prophet Muhammad's birthday. In Daghestan mavlids are also practiced on special occasions, such as birth, marriage, death and shrine holidays.

4 'There is no god but God'.

\section{References}

Hart, Keith and Horacio Ortiz. 2014. The Anthropology of Money and Finance: Between Ethnography and World History. - Annual Review of Anthropology 43 (1): 465-48. DOI: https://doi. org/10.1146/annurev-anthro-102313-025814. 